\title{
TO THE QUESTION ABOUT MEAT FREEZING. REVIEW
}

\author{
Andrey B. Lisitsyn, Irina M. Chernukha, Olga I. Lunina ${ }^{\star}$ \\ V.M. Gorbatov Federal Research Center for Food Systems of Russian Academy of Sciences, Moscow, Russia
}

Key words: meat, freezing, defrosting, quality, pathogens, fresh meat

\begin{abstract}
The overview of studies of freezing and defrosting of raw meat, conducted during the recent years, is presented in the article. The freezing is the most effective method of preserving meat, so developments in this area are in demand by the food industry. There is noted the work on the creation of innovative technologies aimed at the optimizing of the freezing conditions (time, speed), reducing the loss of quality of the frozen products. Affected problems, which are appearing during the defrosting of meat, frozen in fresh and chilled condition. The interest of the use of the meat in the fresh state, which has not been in demand by the industry so far, is returning.
\end{abstract}

\section{Introduction}

The saving of the raw meat quality for a long time is possible due to refrigeration - freezing at low temperatures. Preventing changes in the properties of meat occurs by reducing the rate of microbiological, physico-chemical, biochemical and histological processes as a result of maintaining low temperatures.

In addition to long-term storage, freezing of meat solves many other problems: transportation to remote regions and countries of the world, regulation of supplies in accordance with processing, reducing the amount of food waste.

For such country with so large territory as Russia, the need of the usage of frozen meat will be relevant for a long time. Data on the volume of frozen raw meat in Russia [1] are presented in Table 1. From 9.2 to $18.0 \%$ (not including 2014year, the record for the production of lamb) of meat produced in the country is subjected to refrigeration.

Frosted meat - steamed meat or chilled meat, subjected to refrigeration to a temperature in the muscle thickness at the depth $1 \mathrm{~cm}$ from minus $3{ }^{\circ} \mathrm{C}$ to minus $5{ }^{\circ} \mathrm{C}$, at the depth of $6 \mathrm{~cm}-$ from $0{ }^{\circ} \mathrm{C}$ to $2^{\circ} \mathrm{C}$, during storage the temperature throughout the volume should be from minus $2{ }^{\circ} \mathrm{C}$ to minus $3^{\circ} \mathrm{C}$.

Fresh meat - meat, obtained immediately after slaughter and processing of carcasses or half-carcasses, having a temperature in the muscle thickness not lower than $35^{\circ} \mathrm{C}$. Cooled - obtained immediately after slaughter and processing of carcasses or half-carcasses, having a temperature in the muscle thickness not higher than $12^{\circ} \mathrm{C}$.
Chilled meat - steamed or cooled meat, cooled to a temperature in the muscle thickness from $0{ }^{\circ} \mathrm{C}$ to $4{ }^{\circ} \mathrm{C}$. The shelf life is 16 days.

Frozen meat - fresh meat, or cold meat, or chilled meat, frozen to a temperature in the muscle column is not higher than minus $8^{\circ} \mathrm{C}$. Freezing of meat is carried out to preserve the quality and integrity of meat raw materials for its further use.

Deep freeze - the state of frozen meat, which has a temperature in the muscle column not higher than minus $18^{\circ} \mathrm{C}$. The beef with deep freeze can be stored up to 1 year, the pork -6 months. This method of meat storage is the most reliable from the bacteria effects.

Meat dry (or shock) freezing - the meat, subjected to freezing in the air stream at the temperature minus 30-40 ${ }^{\circ} \mathrm{C}$ (i.e., almost instantly). The meat can be stored at moderate cooling (near $0^{\circ} \mathrm{C}$ ).

Defrosting meat - frozen meat, warmed to a temperature in the muscle thickness not less than minus $1^{\circ} \mathrm{C}$.

\section{Main part}

In the result of freezing the moisture, contained in the meat, came the ice as a result of heat removal at the temperature below cryoscopic. For example, the cryoscopic temperature for beef varies from minus 0.9 to minus $1.5^{\circ} \mathrm{C}\left(\Delta \mathrm{t}=0.6^{\circ} \mathrm{C}\right)$ depending on the $\mathrm{pH}$ level $(\mathrm{r}=$ $+0.73, \mathrm{P}<0.01)[2]$.

In frozen meat in the form of crystals is the main mass water (more $70 \%$ ) [3]. Maximum crystal formation occurs in the temperature range from minus $2{ }^{\circ} \mathrm{C}$ to minus $8{ }^{\circ} \mathrm{C}[4]$.

Table 1. Dynamics of production frozen, frozen and thawed meat in Russia

\begin{tabular}{|c|c|c|c|c|c|c|}
\hline $\begin{array}{c}\text { Types of meat production } \\
\text { (t.tons) }\end{array}$ & $\begin{array}{l}2010 \\
\text { year }\end{array}$ & $\begin{array}{l}2011 \\
\text { year }\end{array}$ & $\begin{array}{l}2012 \\
\text { year }\end{array}$ & $\begin{array}{l}2013 \\
\text { year }\end{array}$ & $\begin{array}{l}2014 \\
\text { year }\end{array}$ & $\begin{array}{l}2015 \\
\text { year }\end{array}$ \\
\hline Frosted meat of the cattle, frozen, deep frozen and defrozen & 43.0 & 38.6 & 36.0 & 1.6 & 43.2 & 51.7 \\
\hline Frosted pork, frozen, deep frozen and defrozen & 57.6 & 61.6 & 58.5 & 67.5 & 97.1 & 108 \\
\hline Frosted lamb, frozen, deep frozen and defrozen, $t$ & 113 & 53.0 & 29.9 & 49.0 & 544 & 124 \\
\hline Total (\% of total meat and byproducts production) & 18.0 & 12.5 & 9.3 & 9.2 & 34.35 & 10.4 \\
\hline
\end{tabular}


Modern methods of freezing are aimed at achieving uniform crystal formation, the formation of small crystals, as well as preventing secondary crystallization, which leads to their increase. Large crystals are increasing the structural cell damage, which leads to the increase in the number of losses of the meat juice, the more intense loss of cell moisture and the high speed of the process of protein denaturation. These processes are reducing the quality of the defrosted product. However, large ice crystals are more stable in long-term storage than small ones. The process of increasing the size of ice crystals is faster at temperatures higher minus $18{ }^{\circ} \mathrm{C}$, and is accelerated by temperature fluctuations during storage, transportation and realization [5].

The degree stage of the structure damage of muscle tissue also depends on the depth of autolytic processes in the meat to the time of freezing. The crystals are localized at the early stages of autolysis inside the muscle fiber during the meat freezing, violations of the structure are minimal. The greatest violations of the morphological structure occur when freezing meat in a state of rigor mortis. Optimal is the processing of meat in the early stages of autolysis with a high $\mathrm{pH}[4]$.

Additional difficulties are created by the size and thickness of the frozen cut or half-carcass, high parameters of which leading to uneven freezing and do not allow the one-time formation of crystals throughout the volume.

Depending on the type of freezing medium, freezing methods are divided into freezing in air, liquid coolants and cryogenic liquids (with liquid nitrogen or carbon dioxide). Depending on the speed of the process, which affects the formation of ice crystals, freezing is divided into: slow, intense and rapid. Rapid freezing contributes to the crystallization of water inside the cells, the formation of small crystals that reduce the degree of damage to the structure of cells.

Abroad, depending on the speed of freezing, the following methods are distinguished: cryogenic freezing $>$ freezing in a high-speed freezer $>$ freezing without air movement [6].

Innovation processes of freezing food are studying at the present time to optimize the settings of the freezing (rate and time) and product quality, using high pressure, using ultrasound, electromagnetic fields, mechanical vibration, etc. $[7,8,9,10]$. For this moment, none of these new methods have been widely used in the meat industry due to high capital and costs.

It is possible to get high-quality products through the use of cryogenic freezing technology, which allows you to freeze the meat for a few minutes using liquefied gas (liquid nitrogen temperature - minus $195^{\circ} \mathrm{C}$ ) or dry ice (temperature - minus $98{ }^{\circ} \mathrm{C}$ ). The advantages of this method include the formation of microcrystalline structure, providing minimal loss of juice during defrosting, preservation of taste and presentation of the product, hygiene, reduction of losses from shrinkage, inhibition of aerobic microflora [6]. To reduce high costs and wide use of this method, it is necessary to minimize gas consumption per unit of production [11].

The possibility of using radiofrequency freezing in addition to cryogenic freezing is being studied. The pork, frozen with pulses of low voltage $(2 \mathrm{kV})$ showed the best cell structure, less number of intercellular voids and less destruction of the cell structure. As a result of this treatment, small ice crystals are formed, well distributed in the intracellular region. The best microstructure of pork after radio frequency freezing is due to the ability of radio frequencies to reduce the freezing point [7].

With the use of high pressure (from 200 to $400 \mathrm{MPa}$ ), there are the following strategies for freezing food: freezing under high pressure, freezing under pressure, freezing with pressure relief [7].

Meat freezing technology with pressure relief («pressure-shift freezing»), provides for cooling the meat to a temperature of minus $20^{\circ} \mathrm{C}$ at elevated pressure [6]. In case of sudden pressure relief in the muscle tissue, there is an instant microcrystallization, which leads to the formation of small uniform ice crystals. After defrosting the meat has improved quality due to minimal changes in tissue structure and reducing the degree of protein denaturation. However, studies on pork and beef have not shown commercial benefits of quality [10].

In order to study the effect of magnetic fields on the freezing process and the quality of meat raw materials $(M$. longissimus dorsi from black pigs), a freezer was created, based on the principle of preserving the super-cooled state below the freezing point, due to the rotation of water molecules around its own axis, both inside and outside the cell under the action of magnetic fields - the «Cell Alive System «(CAS). The results of the study showed that freezing using magnetic fields (at minus $5{ }^{\circ} \mathrm{C}$ ) resulted in a better moisture binding capacity compared to existing freezing methods (in an intense air flow at minus $40^{\circ} \mathrm{C}$, using immersion freezing at minus $65^{\circ} \mathrm{C}$ ) due to the size of ice crystals. They had small crystal sizes throughout the freezing time, and after defrosting, had no effect on the deterioration of meat quality [12]. The use of electro-magnetic vibrations during freezing allows to reduce the number of bacteria and store products for a long time (2-3 years).

In the works on the use of ultrasound, positive effects were obtained for both freezing and defrosting of products $[13,14]$.

The use of microwave radiation during freezing significantly affects the crystallization process. The average size of ice crystals was much lower (62\%) than that of crystals formed during the traditional freezing process. The small size of the crystals resulted in less damage to the microstructure of meat [15].

The direction of research associated with the inhibition of recrystallization is developing. Secondary crystallization can be prevented by adding cryoprotectors (for example, proteins-antifreezes AFP [16], polyphosphates, sorbitol, sucrose, etc. or a combination thereof $[6,17]$. Their func- 
tion is to reduce the temperature of the beginning of the crystallization of moisture, which leads to a change in the growth of ice crystals and slows recrystallization. Formed small ice crystals retain their size in the frozen product throughout the period of its storage.

Introduction of cryoprotectors into chilled pork as part of brine before freezing improves the quality of meat after defrosting (storage temperature minus $18{ }^{\circ} \mathrm{C}$, storage time -60 days.). In the experimental samples of the meat after defrosting, in contrast to the control samples, there was an increase in $\mathrm{pH}$ and water-binding capacity (reduction of meat stiffness), a decrease in damage to the structure of muscle fibers, the preservation of the structure of meat, the absence of undesirable sour smell [17].

Glycogen can be used as a cryoprotector [18]. With high hydration, glycogen can transfer into the bound state of intracellular water. Bound water does not undergo phase changes when exposed to low temperatures, reducing the amount of intracellular ice and crystal sizes. The high content of glycogen in meat can be provided by various feeding strategies, reducing stress in animals before slaughter and slowing the decomposition of glycogen in the process of autolysis.

Recently, interest in the use of fresh meat has been revived [19]. Unfortunately, the technology of meat processing in the steam state is not in demand by the industry, including the freezing of meat in the steam state.

In domestic enterprises of the meat industry, the freezing is mainly performed in the air in a single-phase or twophase manner. Fresh meat is subjected to a single-phase method of freezing. The two-phase method provides for cooling of meat and its subsequent freezing in a cooled state [20].

The advantages of freezing meat in the steamy state are: - reduction of processing time;

- less weight lose during the deboning (2-3\% compared to $8-10 \%$ - in the cooled state);

- production of the meat with higher sanitary and hygienic characteristics;

- the possibility of using vertical deboning;

- reduction of refrigeration space and energy consumption.

The high initial temperature of meat is referred to the disadvantages (pork $-33-35^{\circ} \mathrm{C}$, beef $-36-38^{\circ} \mathrm{C}$ ), a short period during which its functional and technological properties are preserved (for pork -up to 3 hours, for beef, lamb and horse meat - up to 4-6) $[19,21]$. At the stage of defrosting of meat, frozen in the steam state, there is the effect of rigor-thaw-thaw-rigor (muscle rigor), due to the high content of ATP in the steamed meat. The combination of high $\mathrm{pH}(>6,4)$ and temperature $<12{ }^{\circ} \mathrm{C}$ results in a sharp reduction in muscle size [21], leading to a decrease in water binding capacity and structural and mechanical properties. To neutralize this effect, to preserve the quality and reduce high weight loss ( 6.8 times more than when defrosting beef in a cooled state) allows the use of pre-tempering of raw materials or its processing in a frozen state $[22,23]$.
During the defrosting of the frozen meat to the cooled state, this effect is not observed. Meat subjected to twophase freezing in chilled form, as a rule, has no organoleptic differences from meat frozen in steam form, but due to the formation of crystals of larger sizes, there is more damage to tissue structures and, accordingly, higher mass losses during defrosting [22].

Abroad, contrary to Russia, the meat industry is widely used freezing meat in the steam state.

Defrosting (thawing) or partial defrosting (tempering) of frozen meat is usually used at various intermediate stages of processing, as well as before the cooking [24] .

The quality of the defrosted product is influenced by the rate of enzymatic processes, as well as microflora, which has retained its viability during the freezing and storage of the product [25] .

One of the main problems of defrosting is the growth of microorganisms, therefore, when defrosting, temperature regimes should be strictly controlled [24].

Due to the processes occurring in the raw material as a result of storage, the original properties of meat after defrosting are not fully restored, even if the freezing and defrosting processes are carried out under optimal conditions. It is recommended that the defrosting process be carried out slowly, since in this case there is a more complete restoration of the structure of the meat and the binding of the protein structure of the defrosted water, which reduces the loss of meat weight [26].

As a result of temperature decrease in the process of freezing in meat raw materials the course of microbiological and biochemical processes changes. When storing meat raw materials and meat products below minus $10^{\circ} \mathrm{C}$, the growth of microorganisms and enzymatic processes are practically stopped, which minimizes quality losses, but does not stop until the end [6].

The microorganisms, depending on the ability to survive after freezing, frozen storage and defrosting, can be divided into:

- resistant (including Listeria, Staphylococcus and Streptococcus spp.; survive up to $50 \%$ of gram-positive bacteria),

- moderately resistant (most gram-positive bacteria, fungi, and some yeast species) ;

- sensitive (gram-negative bacteria), freezing and storage in a frozen state does not guarantee complete removal of these «sensitive» organisms from frozen foods) [27].

The minimum temperature of growth of microorganisms depends on factors such as $\mathrm{pH}$, water activity (salt concentration) and the presence of oxygen.

It was experimentally established that the beginning of intensive reproduction of microorganisms on the surface of meat during defrosting is in the low plus range - at a meat temperature of $7^{\circ} \mathrm{C}[28]$.

As a result of freezing, many pathogenic microorganisms die, others return to life under favorable conditions. The mechanism of damage to microbial cells during freez- 
ing occurs as a result of mechanical defects caused by ice crystals, drying due to reduced water activity and oxidative damage [10]. Further research is needed to understand the physical and chemical interactions of the food matrix with the microbial cell during freezing and low-temperature storage, and the conditions under which the latter is able to restore its viability. This will identify ways to prevent the recovery of microbial activity. The understanding of these processes will lead to the fact that freezing in the future can be used as a reliable way of preserving food from food pathogens [29].

The safety of thawed meat can be guaranteed provided that the feedstock is of high quality and the refrigeration chain is stable.

In studies on the dynamics of the quantitative content and total composition of pathogenic microflora during storage of frozen beef with different initial microbial state, it was found that when storing beef in a frozen state, the rate of development of psychrotrophic microflora is 3.0-32.6 times higher than mesophilic. It is also noted that the higher the initial microbial contamination of beef, the faster the rate of development of microflora in the process of storing meat in a frozen state, which helps to reduce the shelf life of frozen beef and reduce the hygienic and technological quality of meat. Therefore, when choosing the conditions of meat storage (temperature, duration), the initial microbial state of the carcass surface is important - the amount of psychrotrophic microflora [30].

In the process of freezing and storage, hygienic problems may arise, leading to the detection of pathogenic microflora in frozen meat. Therefore, currently there is a need on the part of the meat industry for simple and fast methods of detection of pathogenic microflora in frozen meat, including Salmonella, thermophilic Campylobacter spp. and other pathogens $[31,32,33]$.

All these factors must be taken into account when defrosting food products.

The defrosting process is undesirable to be carried out slowly, at temperatures above $10 \ldots 15^{\circ} \mathrm{C}$, as conditions are created for the rapid growth and reproduction of pathogenic and harmful organisms [27].
Processes that reduce the quality of meat are accelerated at storage temperatures, especially above minus $5{ }^{\circ} \mathrm{C}$ (minus $5 \ldots$ minus $15^{\circ} \mathrm{C}$ ). For example, oxidation of myoglobin (in fat deposits, in intramuscular lipids of lean meat due to oxidation of phospholipids) occurs most rapidly at a temperature of minus $10^{\circ} \mathrm{C}$.

Inhibition of growth of pathogenic and putrefactive microflora, it is possible to achieve with bioconservative with the use of protective cultures (e.g. lactic acid bacteria) survive in the cold processing, physical processing methods (ionizing irradiation, pressure treatment, etc.), packaging (including packaging under vacuum and in a gas atmosphere, active packaging), comprehensive effects (including a reasonable label) [34].

After defrosting, meat should either be processed immediately or stored at temperatures below $4 . . .5^{\circ} \mathrm{C}$ or subjected to culinary treatment. The growth rate of microorganisms in thawed meat will be the same as in chilled meat (not frozen) under the same conditions of cold storage [24]. Defrosted at different periods of cold storage, during the next 2 days after defrosting at a temperature of $0{ }^{\circ} \mathrm{C}$ to $4^{\circ} \mathrm{C}$ retains the stability of microbiological parameters, normalized SanPiN 2.3.2.1078 and in sanitary and hygienic terms is completely safe for the production of meat products (data of the V.M. Gorbatov Federal Research Center for Food Systems of Russian Academy of Sciences).

\section{Conclusion}

Freezing, as a method of preserving food products, will remain relevant in the near future, as solving of many problems associated with the processing of meat. Research on the development of innovative freezing technologies are carried out in the direction of ensuring minimum losses of quality and safety of food products. The main problem of their widespread use remains high capital and operating costs. Cost reduction at Russian enterprises can contribute to the freezing of meat in the pair condition. Despite the numerous studies carried out on the freezing of fresh meat, and the advantages of this technology, so far the use of meat frozen in the steam state has not been widely used in domestic enterprises of the meat industry, which necessitates further research in this direction.

\section{REFERENCES}

1. Industrial meat production in Russia. [Electronic resource: gks.ru,free_doc/doc_2016/prom16.pdf. Access date 10.04.2018]. (In Russian)

2. Dibirasulaev, M.A., Belozerov, G.A., Dibirasulaev, D.M., Orlovsky, D.E. (2016). Effect of subcryoscopic storage temperature on the quantity of frozen-out water in NOR and DFD beef. Theory and practice of meat processing, 1(2), 18-25. DOI: 10.21323/2414438X-2016-1-2-18-25 (In Russian)

3. Lisitsyn, A.B., Lihatov, N.N., Kudryashov, L.S., Aleksakhina, V.A., Cyernukha, I.M. (2004). Theory and practice of meat processing. M: VNIIMP -378 p. ISBN: 5-901768-14-0. (In Russian) 4. Khortiev, Z.A., Khamitsaeva, A.S., Budaev, F.I. (2017). Changing the properties of meat during freezing and subsequent storage. Scientific and practical conference "Achievements of science - agriculture", 202-206. (In Russian)
5. Belozerov, G.A., Bolshakov, O.V., Dibirasulaev, M.A., Stefanovskiy, V.M. (2015). Recommendations of the International Institute of Refrigeration for the production and storage of frozen food. Part 2. Kholodilnaya Tekhnika, 2, 36-39. (In Russian) 6. Damodaran, S., Pakin, K.L., Fennema, O.R. (2008). Fennema's Food Chemistry 4th ed. CRC Press Taylor\&Fracis Group, Boca Raton, London, New York. -1122 p. ISBN 0849309272-1

7. Cheng, L., Sun, D.-W., Zhu, Z., Zhang, Z. (2017). Emerging techniques for assisting and accelerating food freezing processes: A review of recent research progresses. Critical Reviews in Food Science and Nutrition, 57(4), 769-781. DOI: 10.1080/10408398.2015.1004569

8. Chelombitko, M.A., Pribytok, Yu.N. (2018). Innovative technology of freezing food. $X$ International scientific and practical conference. Minsk: BGATU, 310-314. (In Russian) 
9. James, S.J., C. James, C. (2012). Innovative freezing technologies for foods. [Electronic resource: https://www.newfoodmagazine.com/article/8682/innovative-freezing-technologies-forfoods/ Access date 25.04.2018].

10. James, S.J., C. James, C. (2014). Chilling and Freezing of Foods. Book Chapter in Food Processing: Principles and Applications. Second Edition. p.79-105. DOI: 10.1002/9781118846315.ch5 11. Grishina, I.V., Ishevskiy, A.L., Rodionova, A.L., Shulga, A.S. (2009). Cryogenic freezing of food. Meat branch, 4, 30-32. (In Russian)

12. Ko, K.B. (2013). Effect of magnetic field freezing on porcine Longissimus dorsi muscle quality traits. Proceedings of the 59th International Congress of Meat Science and Technology, Turkey, S7A-4.

13. Delgado, A., Sun, D.W. (2012) Ultrasound-accelerated freezing. Chpt 28, pp645-666. In: Handbook of Frozen Food Processing and Packaging, 2nd Ed, edited by Sun, D.W. CRC Press, Taylor \& Francis Group.-737 p. ISBN: 1-57444-607-X.

14. Hong, G.-P., Chun, J.-Y., Jo, Y.-J., Choi, M.-J. (2014). Effects of water or brine immersion thawing combined with ultrasound on quality attributes of frozen pork loin. Korean Journal for Food Science of Animal Resources 34(1), 115-121. D0I: 10.5851/ kosfa.2014.34.1.115

15. Xanthakis, E., Le-Bail, A., Ramaswamy, H. (2014). Development of an innovative microwave assisted food freezing process. Innovative Food Science and Emerging Technologies, 26, 176181. DOI: 10.1016/j.ifset.2014.04.003

16. Yeh, Ch.-M., Kao, B.-Y., Peng, H.-J. (2009). Production of a recombinant type 1 antifreeze protein analogue by L.lactisand its applications on frozen meat and frozen dough. Journal of Agricultural and Food Chemistry, 57(14):6216-6223. D0I: 10.1021/ jf900924f

17. Semenova, A.A., Veretov, L.A., Kholodov, F.V. (2009). The effect of food cryoprotectants on meat raw materials. Meat branch, 8, 46-49. (In Russian)

18. Sidorenko, Yu.I., Gur'eva, K.B., Ivanova, E.V. (2013). The dynamics of the quality of deep-frozen pork during long-term storage. Meat branch, №3(123), 46-50. (In Russian)

19. Kuznetsova, N.M., Birzolova, A.Yu. (2017). Methods for processing fresh meat. Bulletin of St. Petersburg state agrarian university, 3(48), 94-98. (In Russian)

20. Collegiate Dictionary. Meat industry.(2015) Ed. A.B. Lisitsyn. Moscow: VNIIMP. - 246 p. ISBN 978-5-901768-26-6. (In Russian) 21. Zharinov, A.I., Kudryashov, L.S. (2013). What you should know about fresh meat. Meat industry, 3, 40- 47. (In Russian)

22. Dibirasulaev, M.A., Belozerov, G.A., Arkhipov, L.O. (2017). Development of a spectrophotometric method for the accelerated identification of frozen blocks produced from fresh or chilled meat to justify the choice of technological modes for their defrostation. Vsyo o myase, 5, 48-52. (In Russian)

23. Lisitsyn, A.B., Semenova, A.A., Kapovsky, B.R., Kuznetsova, T.G., Zakharov, A.N. (2017). An innovative method of fine comminution of meat raw material. An alternative to a longstanding tradition. Fleischwirtschaft, 2, 60-65.

24. Belozerov, G.A., Bolshakov, O.V., Dibirasulaev, M.A., Stefanovskiy, V.M. (2015). Recommendations of the International Institute of Refrigeration for the production and storage of frozen food. Part 5. Kholodilnaya Tekhnika, 5, 44-46. (In Russian)

25. Lisitsyn, A.B., Lihatov, N.N., Kudryashov, L.S., Aleksakhina, V.A., Cyernukha, I.M. (2004). Theory and practice of meat processing. Second Edition. M: Editorial service -305 p. ISBN: 9785-9901348-2-9. (In Russian)

26. Koreshkov, V.N., Lapshin, V.A., Khokhlova, L.M., Popov, S.A., Koreshkov, S.V. (2009). Investigation and development of measures on reduction of mass losses in meat and meat products during cold treatment and storage. Vsyo o myase, 1, 9-14. (In Russian)

27. Belozerov, G.A., Bolshakov, O.V., Dibirasulaev, M.A., Stefanovskiy, V.M. (2015). Recommendations of the International Institute of Refrigeration for the production and storage of frozen food. Part 3. Kholodilnaya Tekhnika, 3, 43-44. (In Russian)

28. Dibirasulaev M.A., Belozerov G.A., Arkhipov L.O., Aligadzhiev A.A., Dibirasulaeva P.M., Zaznobina L.E., Zangurin A.S. Method of defrosting meat. RU Patent RF, no 2529915, 2014. (in Russian)

29. Archer, D.L. (2004). Freezing: an underutilized food safety technology? International Journal of Food Microbiology, 90(2), c. 127-138. DOI: 10.1016/S0168-1605(03)00215-0

30. Salata, V. (2018). Characteristics of the composition of the psychrotrophic microflora of frozen beef in the process of storage. Scientific Messenger of Lviv National University of Veterinary Medicine and Biotechnologies, 20(83), 308-313 D0I: 10.15421/ nvlvet8362.

31. Shaltout, F.A., El-Toukhy, E.I., Abd El-Hai, M.M. (2019) Molecular Diagnosis of Salmonellae in Frozen Meat and Some Meat Products. Nutrition Food Technol Open Access, 5(1). DOI: 10.16966/2470-6086.155

32. Paulsen, P., Kanzler, P., Hilbert, F., Mayrhofer, S., Baumgartner, S., Smulders, F.J.M. (2005). Comparison of three methods for detecting Campylobacter spp. in chilled or frozen meat. International Journal of Food Microbiology, 103(2), 229-233. DOI: 10.1016/j.jjfoodmicro.2004.12.022

33. Abbas, B.A., Alghanim, A.M. (2016). Detection of virulence genes in Escherichia coli isolated from frozen meat in Basrah market. Basrah Journal of Veterinary Research, 15(3),134-138. 34. Yaremchuk, N.V. (2009). Fresh products. Opportunities and prospects. Meat branch, 4, 22-25. (In Russian)

\section{AUTHOR INFORMATION}

Andrey B. Lisitsyn - doctor of technical sciences, professor, Academician of the Russian Academy of Sciences, Scientific supervisor , V.M. Gorbatov Federal Research Center for Food Systems of Russian Academy of Sciences, 109316, Moscow, Talalikhina str., 26. Tel: +7-495-676-95-11. E-mail: info@fncps.ru

Irina M. Chernukha - doctor of technical sciences, professor, corresponding member to the Russian Academy of Sciences, leading research scientist of Experimental clinic - laboratory «Biologically active substances of an animal origin», V.M. Gorbatov Federal Research Center for Food Systems of Russian Academy of Sciences. 109316, Moscow, Talalikhina str., 26. Tel: +7-495- 676-97-18

E-mail: imcher@inbox.ru

Olga I. Lunina - candidate of technical sciences, senior research scientist, Department of international scientific and technical cooperation, V.M. Gorbatov Federal Research Center for Food Systems of Russian Academy of Sciences 109316, Moscow,Talalikhina str., 26. Tel: +7-495- 676-97-18. E-mail: o.lunina@fncps.ru

*corresponding author

Authors are equally relevant to the writing of the manuscript, and equally responsible for plagiarism

The authors declare no conflict of interest

Received 10.05.2019 Accepted in revised 06.06.2019 Accepted for publication 20.06.2019 